\title{
Determining the Most Important Factors in House Design with Net Zero Energy Concept (Case study: Cluster X, Perumahan Y, Gading Serpong, Tangerang)
}

\author{
Budijanto Chandra $^{1}$, Samsu Hendra Siwi ${ }^{1}$, Naniek Widayati Priyomarsono ${ }^{1}$, Fermanto \\ Lianto ${ }^{1}$ \\ ${ }^{1}$ Department of Master Architecture, Universitas Tarumanagara \\ budijantochandra@gmail.com
}

\begin{abstract}
The most significant environmental problem recently is global warming and causing environmental damage and threatening human life. It needs to immediately reduce $\mathrm{CO}_{2}$ emissions from burning fossil fuels as a cause of global warming, and one way is to reduce the energy of fossil fuels in buildings and replace them with renewable energy. It is necessary to immediately apply the Net Zero Energy Building (NZE), which can significantly reduce the use of fossil fuels and use energy renewable. This study is to find out what needs to be considered in house design with NZE concepts in the context of tropical and humid climates such as in Jakarta and its surroundings. The method used is qualitative research with a case study approach. NZE buildings have the potential to be applied in by taking into account some of the NZE's house design guidelines.
\end{abstract}

(C) 2019 IJBESR. All rights reserved.

Keywords: Global Warming, Net Zero Energy, Renewable Energy, House Design

\section{Introduction}

Climate change, which is characterized by the phenomenon of Global Warming, has resulted in severe environmental problems and can damage the environment and ecosystems. The damage could be such as changes in irregular weather patterns, extreme weather, changes in the harvest season for staple crops, prolonged dry season, extreme heatwaves, higher rainfall than before, melting of polar ice caps, rising sea levels and some species of animals threatened with extinction because their habitats undergo extreme changes and affect human health. Global warming is caused by greenhouse gas (GHG) emissions, or what is often called $\mathrm{CO}_{2}$ emissions because $\mathrm{CO}_{2}$ gas dominates the most significant portion of greenhouse gases in the atmosphere. $\mathrm{CO}_{2}$ emissions because heat reflected from the earth's surface to escape the atmosphere because it is blocked by greenhouse gases and causes the average temperature of the earth's surface to rise. These $\mathrm{CO}_{2}$ emissions occur due to the burning of fossil fuels such as coal, natural gas, and petroleum. Even the city of Jakarta has experienced the highest average temperature rise over the past 130 years. It is higher than the trend of increasing average global temperatures in the last few decades [1].

The phenomenon of global warming has pushed the United Nations (UN) to produce the Paris Agreement 2015 (COP21), which limits the increase in the average temperature of the earth's surface globally should not exceed $2^{\circ}$ Celsius until the end of the 21 st century. An increase in temperature that exceeds $2^{\circ}$ Celsius will cause damage to the environment and disasters that are very dangerous for human life and other species. Besides, the Paris Agreement 2015 also set a target to achieve a net-zero emission between 2050 and 2100. 
The achievement of net-zero emission can be done by using renewable energy [2]. Indications of a worsening impact on climate change have led to a significant reduction in fossil energy, one of which is by building NZE. There are no house design guidelines with the concept of NZE in Indonesia.

NZE houses are houses that are designed to produce huge energy savings (more than $40 \%$ ), and then the energy needed is supplied by renewable energy. Because the initial design of a house with the NZE concept is essential to determine the success of the NZE target, the house design needs to pay attention to some crucial design indicators. This study is to learn indicators primarily for success in house design with the NZE concept.

This method used is a qualitative method with a case study approach in Cluster X, Perumahan Y, Gading Serpong, Tangerang. The research method was also assisted with an EDGE energy calculation program. Research locations are the Jakarta area and its surroundings. Research is focused on essential aspects of the passive design, and renewable energy used is solar panels.

\section{Material and Methods}

The concept of NZE building is defined in two keywords, namely efficiency performance in one operational year and renewable energy, where energy consumption in one operational year is met equal or greater by renewable energy [3].

The NZE building is a high energy efficiency building so that energy use is deficient and is met by the use of renewable energy technology [4]. This NZE building is a practical way to save costs on energy loads, utilize clean solar energy and wind technology, to protect the environment and improve the quality of life for building users [5].
Illustration of the explanation of the NZE building concept can be seen in Figure 1.

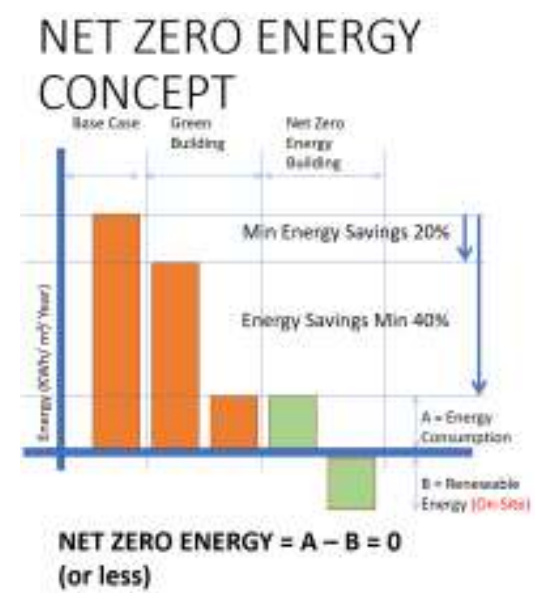

Figure 1: Net Zero Energy Concept Source: Private documentation from various sources, 2019

From these concepts, it can be concluded that NZE buildings are buildings that use highly energy-efficient and that energy needs are met all or more by renewable energy on-site. Measurement of NZE performance in the actual use of energy use throughout the building's operational year.

\subsection{Solar Responsive Design}

Because house design with the NZE concept requires $40 \%$ or more energy for tropical and humid climates, it is necessary to consider the most significant saving potential, namely the cooling load of the room. The cooling load of this room due to the heat of radiation from the sun's rays entering the room makes the occupants uncomfortable and turns on the Air Conditioner (AC).

House design suitable for tropical and humid climates is a passive design that is an energysaving method by utilizing energy from nature without the use of electrical equipment [6]. For humid tropical climates, the passive design also called solar responsive design includes: 
avoiding the heat, rejecting heat, and utilizing energy from nature [7].

The Solar Responsive Design examined in this study are Building Orientation, Window to Wall Ratio (WWR), Shading Elements and Renewable Energy.

\subsubsection{Orientation}

Orientation is the primary indicator of house design with the NZE concept. Because the sun's path to Jabodetabek, especially Tangerang, is located in the South Latitude (LS), it is slightly inclined to the north (see figure 2).
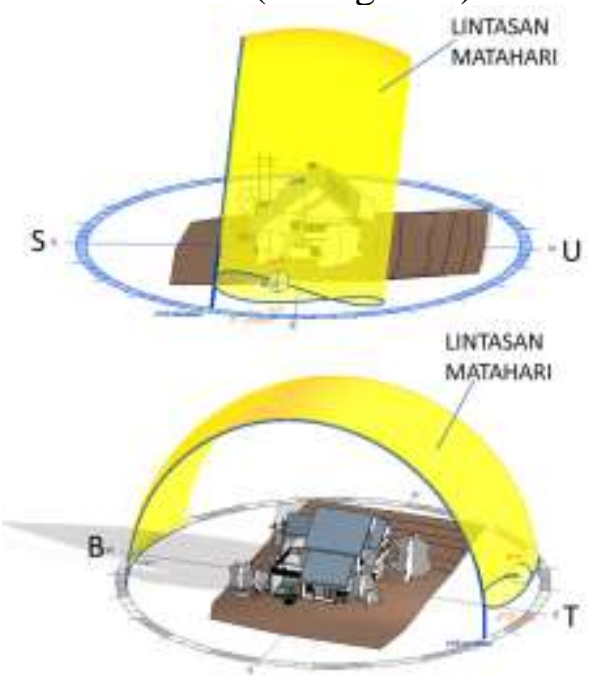

Figure 2: Sun Path in the South Latitude Location

Source: Private documentation, 2019

The orientation of the building to the north or south and highly recommended the primary direction of the building facing south because most of the room is not exposed to direct solar radiation. The orientation of this building will also relate to the placement of solar panels that have high efficiency. The primary orientation of the building can also face South to Southeast because it is also the best orientation that has the minimum solar radiation factor $(\mathrm{SF})$ (see Table 1).

Table 1: Solar Factor for various orientation in Jakarta

Orientas

\begin{tabular}{|c|c|c|c|c|c|c|c|}
\hline$U$ & TL & T & TGR & S & ED & B & BL \\
\hline 130 & 113 & 112 & 97 & 97 & 176 & 243 & 211 \\
\hline
\end{tabular}

Source: BSN, 2016

\subsubsection{Window to Wall Ratio (WWR)}

In tropical climates, it is necessary to pay attention to the heat of solar radiation entering the room, which makes the cooling load of the room increases. The heat radiation from sunlight entering the building through the building envelope can be calculated by Overall Thermal Transfer Value (OTTV) (see figure 3).

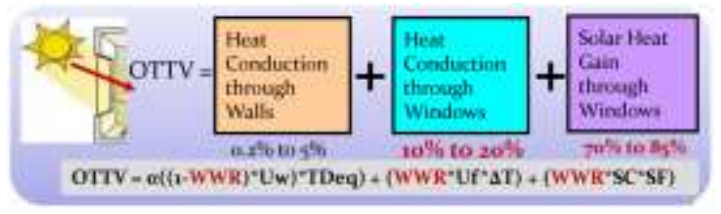

Figure 3: Overall Thermal Transfer Value (OTTV) Source: AGC Group, 2016

Heat radiation from sunlight enters the room through 3 ways: conduction through walls, conduction through glass, and heat entering through transparent wall openings. Of the three heat transfers, the heat passing through transparent wall openings is the largest at $70 \%$ $-85 \%$, and this is what we need to consider in designing NZE houses to get maximum energy savings.

A significant factor that influences the size of the OTTV value is the Window to Wall Ratio (WWR), which is the ratio between openings and walls. Energy savings through lowering WWR can save energy up to $20 \%$ or more.

\subsubsection{Shading Devices}

Every glass opening should be equipped with an overhang just above the upper lip of the window to provide a barrier to heat radiation entering the house. The shade elements can be horizontal, vertical, and egg crate shades, and the minimum shade length is the same as the window height for the horizontal shade, and the minimum is the same width as the window width for the vertical shade. Note the angle of sunlight in the morning and evening are small, so that the shade elements can effectively 
provide shade for all parts of the glass opening (see figure 4).

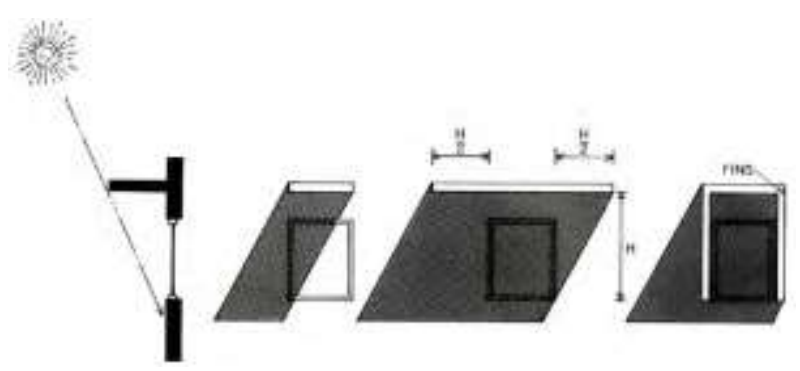

Figure 4: Various shading devices and shading effect Source: Lechner, 2015

\subsection{Renewable Energy}

Renewable energy (renewable energy) is an energy that comes from active local natural energy sources that are always available and not used up. Conversely, non-renewable energy (non-renewable energy) is energy derived from static sources that will remain in the soil if not released by human activities [8], where for tropical climates such as in Indonesia, it is strongly recommended to use renewable energy in the form of solar panels.

\subsection{Methods}

The research methodology uses qualitative research with a case study approach where this methodology uses empirical evidence (not the results of laboratory experiments) to prove whether a theory can be implemented in a condition or not [9] — data collection through interviews, observations, and document review.

The analysis was assisted with an energy calculation program from EDGE (Excellence in Design for Greater Efficiencies), which is also one of the green building certifications used in Indonesia. The object study is the type of 2story house with a building size of $9 \mathrm{~m} \times 16 \mathrm{~m}$ in Cluster X, Perumahan Y, Gading Serpong, Tangerang.

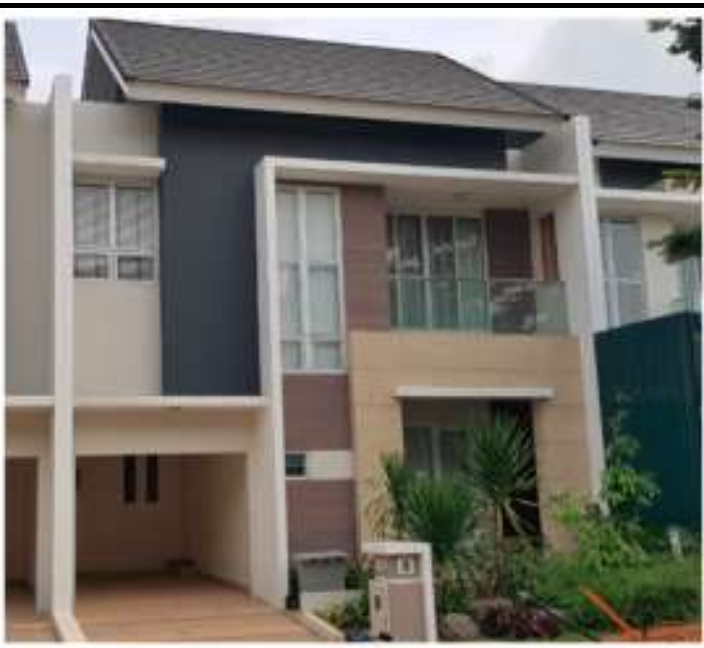

Figure 5: Object study house at Cluster X, Perumahan Y, Gading Serpong, Tangerang Source: Private documentation, 2019

\section{Results and Discussions}

From observations, interviews, and data from the study object, an analysis was made to get energy savings from a $9 \mathrm{~m} \times 16 \mathrm{~m}$ type house in Cluster X, Perumahan Y, Gading Serpong, Tangerang.

\subsection{Energy savings calculation}

The results of the calculation of energy savings with the help of the EDGE energy calculation program found that the house can save energy by $54.03 \%$ which can be broken down as follows: Energy savings from reducing Orientation and WWR $=20.65 \%$, Shading Elements $(\mathrm{AASF})=2.56 \%$, LED lights $=$ $19.38 \%$ and Renewable energy $=11.44 \%$.

From the graph, it can be seen that the most significant savings are on cooling energy obtained from the Solar Responsive Design of the house in the form of Orientation, WWR, and Shading Devices. Besides, this house uses renewable energy in the form of solar panels, which also adds to energy savings. Also, there are also savings through energy-saving lamps (see figure 6). 


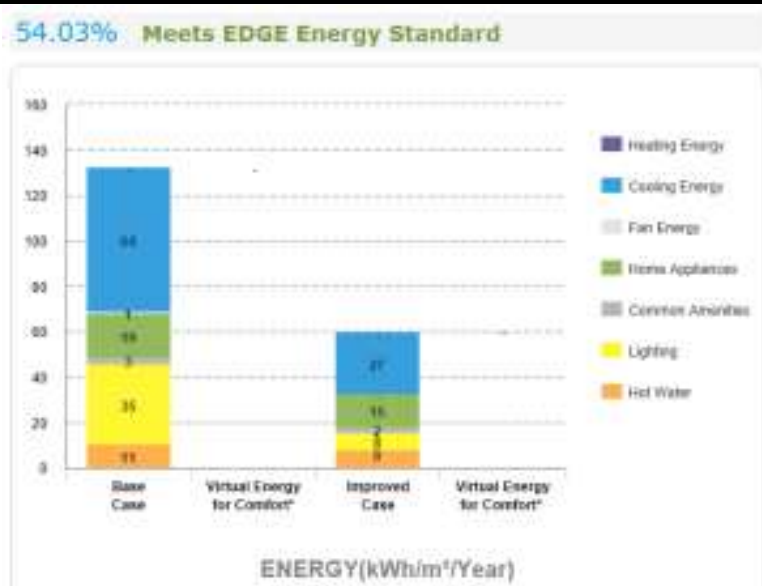

Figure 6: Energy savings of house at Cluster X, Perumahan Y, Gading Serpong, Tangerang Source: EDGE Apps, 2019

\subsection{Orientation}

The orientation of the building in the cluster is very supportive because it faces north and south, and this is an indicator of the leading NZE houses (see figure 7). It also supports the placement of favorable solar panels, and solar panels are usually placed on the roof of the house facing the back. Orientation also affects energy savings on WWR and shading devices (AASF).

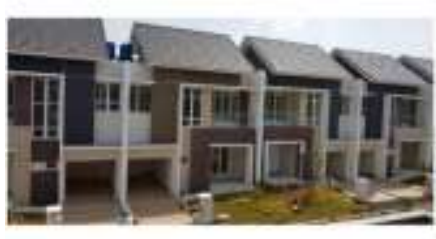

Figure 7: Houses at Cluster X, Perumahan Y, Gading Serpong, Tangerang

Source: Private documentation, 2019

\subsection{Window to Wall Ratio (WWR)}

The second indicator is the ratio of wall openings in the form of glass to the wall (WWR) is significant in reducing energy significantly because it can reduce heat radiation entering through the glass window so that the cooling load of the room is reduced. The WWR ratio in this house type is very low at $11 \%$, which is caused by: -limitation of openings to the west and east, where the west area is used as a service area that does not need window openings.

-maximum aperture is preferred in the north or south orientation, this is very beneficial because it reduces the amount of solar heat radiation.

\subsection{Shading Devices}

The optimal shade element (overhang) prevents sunlight from entering the room is on the window sill. The sufficient length of the shade element is one that has the length (D) equal to or greater than the height of the window $(\mathrm{H})$. In some parts of the house, there are still less effective shading elements $(\mathrm{D}=\mathrm{H} / 3)$, like Figure 8. The efficient shade effect is on the north and south facades, as shown in Figure 9.

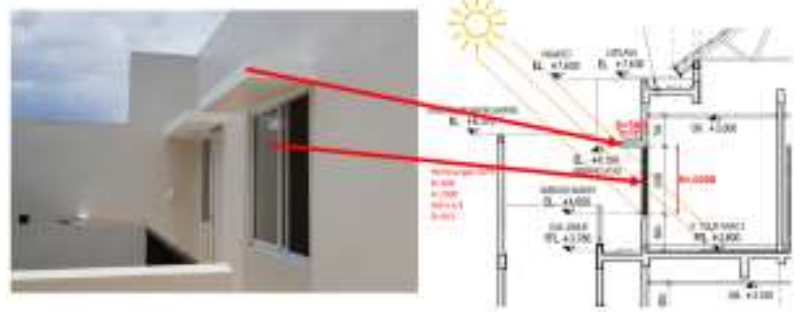

Figure 8: Shading devices that is not efficient Source: Private documentation, 2019

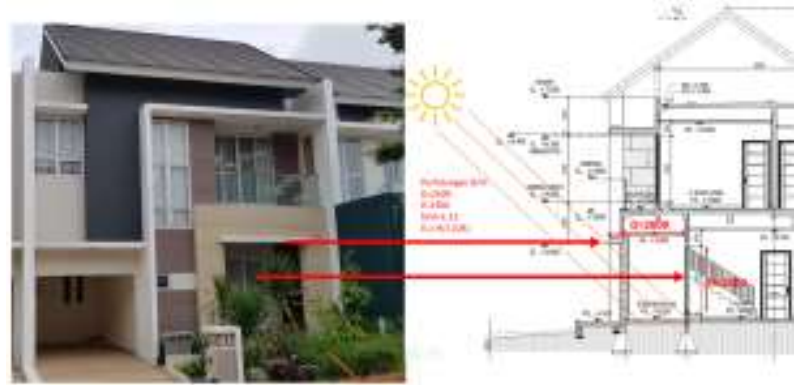

Figure 9: Good Shading devices and self-shading Source: Private documentation, 2019

\subsection{Renewable Energy}

Renewable energy usage is required in NZE homes, which can be in the form of solar, wind, and biomass panels. For the climate in Indonesia, it is highly recommended to use solar panels, because the sun shines full all year. In areas located in South Latitude, such as in Tangerang, solar panels will work more efficiently when facing north, the arena of the 
sun's trajectory in the South Latitude area tends to move north. The placement of solar panels can be seen in figure 10 .

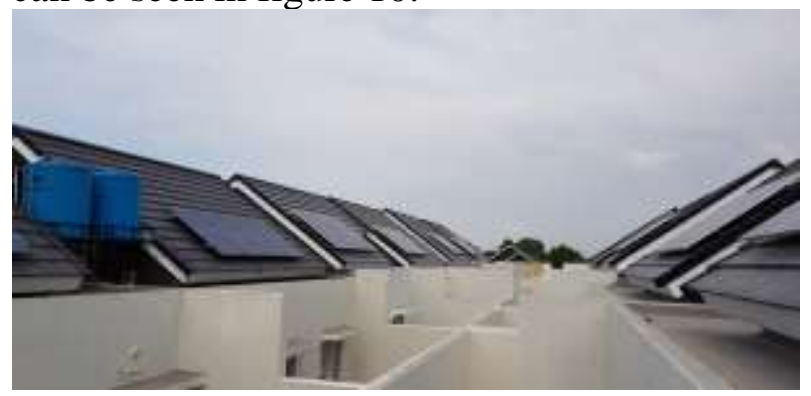

Figure 10: Solar Panel installation Source: Private documentation, 2019

\section{Conclusion}

Based on the analysis and discussion, it can be concluded several things:

- The design of the house with the concept of NZE can be applied in the Greater Jakarta area, especially in the Tangerang area.

- The design of the NZE home must be designed at the earliest stage because it is the key to success in achieving the NZE home target.

- There are four important factors in home design with the NZE concept, namely: Orientation, Window to Wall Ratio (WWR), Shading Devices (AASF), and Renewable Energy because these four factors can save enormous energy.

- Passive Design or Solar Responsive Design is essential in the Design of Houses with the concept of NZE for the humid tropics, even important in the Design of Houses that cannot be separated from the environmental, human, and building context itself.

- Energy-efficient homes will also save on the cost of monthly electricity bills and are also healthier for the residents.

- Regulations regarding renewable energy and their use need to be regulated immediately and need support from the government to promote renewable energy.

- The government needs to immediately make regulations regarding NZE buildings so that the development of NZE buildings can begin in Indonesia.

- It is necessary to proceed with NZE research for other types of buildings besides houses.

\section{Acknowledgement}

We thank Direktorat Penelitian dan Pengabdian Kepada Masyarakat Fakultas Teknik Universitas Tarumanagara Jakarta 2019 research scheme for funding this work.

\section{References}

[1] S. Siswanto, J. V. G. Oldenborgh, V. D. G. Schrier, R. Jilderda and V. D. B. Hurk, "Temperature, extreme precipitation, and diurnal rainfall changes in the urbanized Jakarta city during the past 130 years," International Journal of Climatology, pp. 120, 2015.

[2] United Nations, Paris Aggreement, Paris: United Nations, 2015.

[3] T. Hootman, Net Zero Energy Design : A Guide for Commercial Architecture, Hoboken, NJ: John Wiley \& Sons, Inc., 2013.

[4] D. Crawley, S. Pless dan P. Torcellini, "Getting to Net Zero," Innovation for Our Energy Future, Vol. \%1 dari \%2NREL/JA-550-46382, September 2009.

[5] C. Eley, Design Professional's Guide to Zero Net Energy Buildings, Washington, DC: Island Press, 2016.

[6] Y. M. Ardiani, Sustainable Architecture: Arsitektur Berkelanjutan, Jakarta: Penerbit Erlangga, 2015.

[7] N. Lechner, Heating, Cooling, Lighting, Hoboken, New Jersey: John Wiley \& Sons, Inc., 2015.

[8] J. Twidell dan T. Weir, Renewable Energy Resources, Abingdon: Routledge, 2015.

[9] S. Sarosa, Penelitian Kualitatif - Dasar-Dasar, Jakarta: Penerbit Indeks, 2017. 